\title{
Extractable manganese in the southeastern East China Sea shelf and the Okinawa Trough
}

\author{
Ching-Ling WEI ${ }^{\mathrm{a} *}$, George T.F. WONG ${ }^{\mathrm{b}}$, Sou-Jen SUN ${ }^{\mathrm{a}}$, Gwo-Ching GONG ${ }^{\mathrm{c}}$ \\ a Institute of Oceanography, National Taiwan University, PO Box 23-13, Taipei, Taiwan, ROC \\ ${ }^{\mathrm{b}}$ Department of Ocean, Earth and Atmospheric Sciences, Old Dominion University, Norfolk, VA 23529-0276, USA \\ ${ }^{c}$ Department of Oceanography, National Taiwan Ocean University, Keelung, Taiwan, ROC
}

Received 11 May 1999; revised 14 April 2000; accepted 28 April 2000

\begin{abstract}
The distribution of extractable manganese, which is likely to be similar to dissolved manganese, in a transect from the mid-shelf of the southeastern East China Sea Shelf across the Kuroshio to the Okinawa Trough was determined in May 1991. In the surface layer above $200 \mathrm{~m}$, the higher concentrations of extractable manganese ( 5 to $6 \mathrm{nM}$ ) are found at the most shoreward station. Mixing between the shelf water and the Kuroshio results in a tongue of manganese-rich water $(>3 \mathrm{nM})$ extending from the shelf into the Okinawa Trough. In contrast, the Kuroshio surface water and the upwelling Kuroshio subsurface water, both with concentrations of $<3 \mathrm{nM}$, are manganese-poor. Thus, during upwelling and frontal exchanges, manganese-poor water is imported into the East China Sea Shelf while manganese-rich water is exported to the Kuroshio. A box-model calculation for the cycling of extractable manganese in the East China Sea Shelf-Huang Hai-Bo Hai system indicates that the manganese cycle in this shelf-sea system is dominated by the exchanges between the water column and the sediments. The benthic flux of manganese from the shelf sediments to the water column $\left(190 \times 10^{7}{\left.\text { mole } y e a r^{-1}\right)}\right.$ and the scavenging removal of manganese from the water column to the shelf sediments $\left(180 \times 10^{7}{\left.\text { mole } y e a r^{-1}\right)}\right.$ are about equal to each other so that they may constitute an approximately closed cycle. While the shelf is a net source of manganese to its adjoining waters, the export of manganese from the shelf (20 $\times 10^{7}$ mole $_{y e a r^{-1}}$ ) is about an order of magnitude smaller than the benthic flux. The inputs of manganese to the system from the rivers $\left(3 \times 10^{7}\right.$ mole $\left.\cdot y e a r^{-1}\right)$, the intrusion of Kuroshio surface water $\left(4 \times 10^{7}\right.$ mole.year $\left.{ }^{-1}\right)$ and the upwelling of Kuroshio subsurface water $\left(2 \times 10^{7}{\left.\text { mole } \cdot y e a r^{-1}\right)}\right.$ are of similar magnitude but are yet another order of magnitude smaller. Thus, the export of manganese from the shelf cannot be sustained by these inputs of manganese to the shelf. Furthemore, the sum of the inputs from the Kuroshio is larger than the riverine input. In the deep water $(>600 \mathrm{~m})$ of the Okinawa Trough, as the concentration of oxygen decreased steadily with depth, higher concentrations of extractable manganese (3 to $15 \mathrm{nM}$ ) were found. Superimposed on these generally elevated concentrations of extractable manganese, there were two distinct layers of manganese-rich water at about 700 to $1000 \mathrm{~m}$ and 1300 to $1500 \mathrm{~m}$. The former coincided approximately with the depth of the bottom of the pycnocline and with the depth of the band of organic-rich fine-grain sediment which lies along the lower shelf-upper slope at the northern flank of the Okinawa Trough. The latter coincided approximately with the depth of some known hydrothermal vent fields in the Okinawa Trough. However, whether these layers of manganese-rich water are linked to these oceanographic phenomenon cannot yet be established definitively. (C) 2001 Ifremer/CNRS/IRD/Éditions scientifiques et médicales Elsevier SAS
\end{abstract}

Résumé - Manganèse extractible dans le sud-est de la Mer de Chine Orientale et la fosse d'Okinawa. La répartition du manganèse extractible, probablement similaire à celle du manganèse dissous, a été déterminée en mai 1991 sur une radiale partant du milieu du plateau continental dans le sud-est de la Mer de Chine Orientale et traversant le

*Correspondence and reprints.

E-mail address: weic@ccms.ntu.edu.tw (C.L. WEI).

(C) 2001 Ifremer/CNRS/IRD/Éditions scientifiques et médicales Elsevier SAS. Tous droits réservés

S0399178400011129/FLA 
Kuroshio jusqu'à la fosse d'Okinawa. Dans les $200 \mathrm{~m}$ superficiels, les concentrations les plus élevées (5 à $6 \mathrm{nM})$ sont trouvées à la station la plus côtière. Le mélange entre l'eau côtière et le Kuroshio forme une langue d'eau riche en manganèse (plus de $3 \mathrm{nM}$ ) entre le plateau continental et la fosse d'Okinawa. Au contraire, l'eau superficielle du Kurioshio et l'eau sub-superficielle de l'upwelling du Kuroshio sont pauvres en manganèse (moins de $3 \mathrm{nM}$ ). Ainsi, pendant les échanges dans l'upwelling et dans le front, l'eau pauvre en manganèse arrive sur le plateau continental de la Mer de Chine Orientale tandis que l'eau riche en manganèse est transférée au Kurioshio. Un modèle en boîtes du système formé par le plateau continental de la Mer de Chine Orientale, la Mer Jaune et le golfe de Bo Hai indique que le cycle du manganèse y est dominé par les échanges entre la colonne d'eau et les sédiments du plateau continental. Les flux benthiques de manganèse dans le sens sédiments - colonne d'eau $\left(190 \times 10^{7} \mathrm{~mol} \mathrm{an}^{-1}\right)$ et dans le sens colonne d'eau - sédiments $\left(180 \times 10^{7} \mathrm{~mol} \mathrm{an}^{-1}\right)$ sont équivalents et forment un cycle à peu près fermé. Alors que le plateau est la principale source de manganèse pour les eaux adjacentes, l'export de manganèse par le plateau $\left(20 \times 10^{7} \mathrm{~mol} \mathrm{an}^{-1}\right)$ est d'un ordre de grandeur inférieur au flux benthique. Les apports de manganèse en provenance des rivières $\left(3 \times 10^{7} \mathrm{~mol}\right.$ $\left.\mathrm{an}^{-1}\right)$, de l'eau superficielle du Kurioshio $\left(4 \times 10^{7} \mathrm{~mol} \mathrm{an}^{-1}\right)$ et de la remontée d'eau sub-superficielle du Kurioshio $(2 \times$ $10^{7} \mathrm{~mol} \mathrm{an}^{-1}$ ), comparables entre eux, sont encore d'un ordre de grandeur inférieur et ne peuvent équilibrer l'export de manganèse par le plateau continental. De plus, le total des apports par le Kurioshio est supérieur à celui des rivières. L'eau profonde (plus de $600 \mathrm{~m}$ ) de la fosse d'Okinawa où la teneur en oxygène diminue régulièrement avec la profondeur, présente de fortes concentrations en manganèse extractible ( 3 à $15 \mathrm{nM}$ ), avec deux couches d'eaux riches en manganèse, l'une à 700-1 000 m et l'autre à 1300-1500 m; la première coïncide approximativement avec le bas de la pycnocline et avec la couche de sédiment fin riche en matière organique qui s'étend au bas du plateau le long du flanc nord de la fosse d'Okinawa ; la deuxième coïncide approximativement avec quelques champs d'évents hydrothermaux de la fosse d'Okinawa. Cependant, il n'est pas certain que ces couches d'eaux riches en manganèse soient liées à ces phénomènes océanographiques. (C) 2001 Ifremer/CNRS/IRD/Éditions scientifiques et médicales Elsevier SAS

\section{East China Sea / manganese / Kuroshio}

\section{Mer de Chine Orientale / manganèse / Kurioshio}

\section{INTRODUCTION}

The shelf seas serve as the link between the continents and the open oceans. Land-derived material is delivered to the shelf seas via the rivers and then exported to the open oceans during material exchanges between the shelf seas and the oceans. However, the shelf seas do not act simply as an inert conduit for delivering land-derived material to the oceans. While they constitute only a small fraction of the world oceans by volume, they are biogeochemically more reactive than the average ocean (Walsh et al., 1988). Through these biogeochemical processes, the shelf seas can modify the quantity as well as the quality of the land-derived material that ultimately reaches the oceans. Thus, an understanding of the biogeochemical processes in the shelf seas is critical for assessing the interactions between the land and the oceans.

The marine geochemistry of manganese has been studied rather extensively (e.g., Bender et al., 1977; Klinkhammer and Bender, 1980; Landing and Bruland, 1980;
Martin and Knauer, 1980, 1984; Bruland and Franks, 1983; Donat and Bruland, 1995) not only because manganese participates in a wide variety of geochemical processes but also because its geochemical behavior may drive the behavior of other trace elements. The distribution of manganese in the water column is strongly affected by external sources and sinks (Heggie et al., 1987; Klinkhammer et al., 1997), by hydrothermal processes (Klinkhammer and Hudson, 1986; Mottl et al., 1995), and by redox condition (Landing and Bruland, 1980; Martin and Knauer, 1982, 1984; Martin et al., 1985).

The East China Sea is made up of the water on the East China Sea Shelf (also known as the Tunghai Shelf), and the water in the deep Okinawa Trough (Wong et al., 2000a). The former constitutes one of the larger and more productive shelf seas of the world. It extends from the Cheju Island, at about $33^{\circ} 20^{\prime} \mathrm{N}$, in the north to the northern coast of the island of Taiwan, at about $25^{\circ} \mathrm{N}$, in the south. It communicates freely with the land-bound Huang Hai (or Yellow Sea) and Bo Hai through the 
western portion of its northern boundary. At the eastern end of its northern boundary, water is exported to the Japan Sea through the Tsushima Strait. To the west, the East China Sea Shelf-Huang Hai-Bo Hai system is bounded by continental China from which it receives the runoffs of two major rivers of the world, the Changjiang (or the Yangtze River) and the Huanghe (or the Yellow River), in addition to a host of smaller rivers. To the east, the East China Sea Shelf is bounded at the western side of the Okinawa Trough by the Kuroshio which flows into the Okinawa Trough from the Philippine Sea through the Suao-Yunaguni Pass. Extensive exchanges between the East China Sea Shelf and the Kuroshio occur through frontal processes and topographically-induced upwelling. Since the Kuroshio eventually flows into the northwestern Pacific through the Tokara Strait after it has traversed through the Okinawa Trough, it acts as a conduit through which indirect material exchanges between the East China Sea Shelf-Huang Hai-Bo Hai system and the open Pacific may occur. The Okinawa Trough is a tectonicallyactive area where extensive hydrothermal activities have been found (Ishibashi et al., 1988; Lallemand et al., 1997). Furthermore, the East China Sea is also located in the path of the eolian transport of material from central Asia so that it receives one of the highest fluxes of atmospherically-deposited mineral aerosols to the world oceans (Duce et al., 1991). Thus, a multitude of processes that can affect the biogeochemical behavior of manganese may operate in this environment. In order to investigate the biogeochemical behavior of manganese in this rather complex system, a transect of ten stations extending from the shallow East China Sea Shelf to the deep Okinawa Trough was sampled in order to construct the crosssectional distribution of manganese in the southeastern East China Sea.

\section{MATERIALS AND METHODS}

\subsection{Sampling}

Ten stations were occupied at about $25-\mathrm{km}$ intervals, in a transect which ran approximately normal to the isobaths, from about the mid-point of the southeastern East China Sea Shelf, at $200 \mathrm{~km}$ from the Chinese coast at $121.9^{\circ} \mathrm{E}$ and $26.2^{\circ} \mathrm{N}$, to the Okinawa Trough at $123.2^{\circ} \mathrm{E}$ and $24.8^{\circ} \mathrm{N}$, between 2 and 6 May 1991 aboard the R/V Ocean Researcher I during Cruise 280 of the Kuroshio
Edge Exchange Processes (KEEP) Study (Wong et al., 2000b; figure 1). At each station, the distribution of temperature and salinity were recorded with a Seabird model SBE9/11 conductivity-temperature-depth (CTD) recorder. Discrete water samples were collected with Teflon-coated 2.5-L Niskin or Go-Flo bottles (General Oceanics, Miami, FL) mounted on a rosette sampler for the determination of salinity, oxygen, nitrate and phosphate. At seven selected stations along the transect, sub-samples drawn from the Go-Flo bottles were obtained for the determination of extractable manganese.

\subsection{Instruments and methods}

Salinity in discrete water samples was determined in our shore-based laboratory with an AUTOSAL salinometer which had been calibrated with certified IAPSO standard sea water. The precision of the measurement was about \pm 0.001 (Fang et al., 1990).

Oxygen was determined spectrophotometrically on board of the ship, by measuring the absorbance of the tri-iodide ions formed in the classical Winkler titrimetric method (Carpenter, 1965; Pai et al., 1993), with a precision of about $\pm 0.2 \%$.

Phosphate was determined manually on board of the ship by the method of Murphy and Riley (1962), with a precision of $\pm 3 \%$. Nitrate was also determined on board of the ship by the cadmium-copper reduction/pink azodye method (Strickland and Parsons, 1972), which had been adapted for use with a flow-injection analyzer (Pai et al., 1990a), with a precision of $\pm 1 \%$.

Extractable manganese was determined by the method of Pai et al. (1990b). Briefly, unfiltered seawater was drawn from a Go-Flo bottle directly into an acid-cleaned 1.25-L polypentene (PET) bottle. Then, immediately, while still on board of the ship, manganese was extracted from the sample onto Chelex-100 resin beads by passing it at its natural $\mathrm{pH}$ by gravity directly from the PET bottle through a pre-packed Chelex-100 column $(5 \mathrm{~cm}$ long with a $0.5-\mathrm{cm}$ diameter), which had been conditioned to a $\mathrm{pH}$ of 6.5 , at a flow rate of $4-5 \mathrm{~mL} \cdot \mathrm{min}^{-1}$. This extraction process was completed within several hours after sample collection. The column was then stored in the dark at $20{ }^{\circ} \mathrm{C}$ and returned to a class- 100 clean room in a shore-based laboratory for further processing. In the clean room, the salts and major cations were removed by 


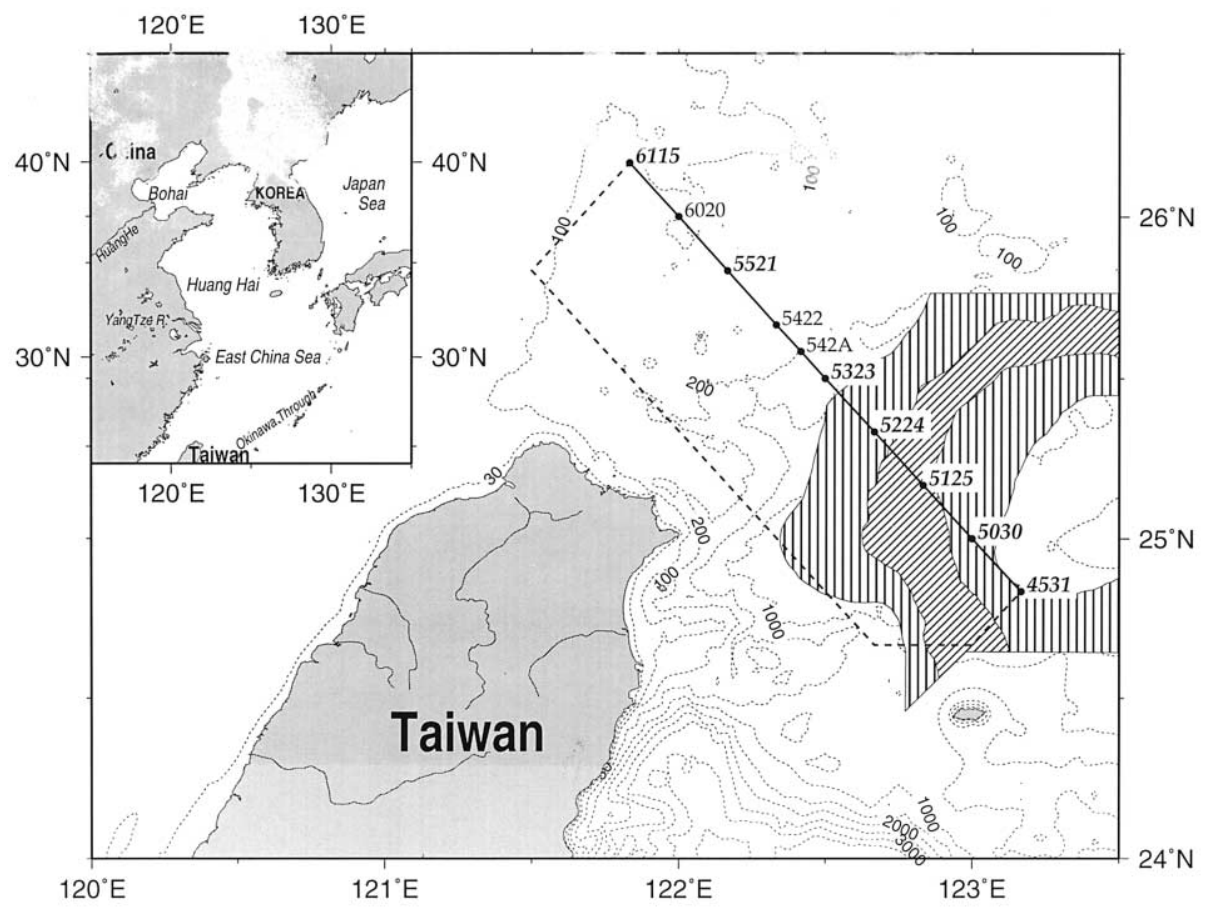

Figure 1. Station locations and the bathymetry of the study area. The rectangle in the map shows the cruise track for repeated hydrographic survey during Kuroshio Edge Exchange Processes (KEEP) project. The locations of the organic-rich sediments (Lin et al., 1992) are also shown (the hashed area with diagonal and vertical lines indicates organic carbon contents higher than 0.7 and $0.6 \%$, respectively) Depth intervals are given in meters. eluting the column successively with five $1-\mathrm{mL}$ aliquots of sub-boiled distilled de-ionized water (DDW), four 5-9-mL aliquots of a $0.5 \mathrm{M}$ ammonium acetate solution adjusted to a $\mathrm{pH}$ of 5.5, and five 1-mL aliquots of DDW again. Then, manganese was eluted from the column with four 1-mL aliquots of $2 \mathrm{~N} \mathrm{HNO}_{3}$, and was determined in this elute by flameless atomic absorption spectrophotometry using a Hitachi model Z8100 atomic absorption spectrophotometer equipped with Zeeman background correction and an autosampler. All reagents were prepared with sub-boiled DDW. Nitric acid was also purified by sub-boiling. The precision and detection limits of the method were $\pm 9 \%$ and $0.02 \mathrm{nM}$ respectively (Wei et al., 1991). The manganese concentration thus determined is designated as extractable manganese.

Chelex-100 efficiently extracts dissolved manganese from approximately neutral solutions. Thus, this extractable manganese should include all of the dissolved manganese in the sample. However, since the unfiltered sample was passed through the Chelex-100 column directly so as to minimize any sample contamination, it is possible that some manganese in particulate form might also have leached out, and was determined in this analytical scheme. Nonetheless, for several reasons the contribution of particulate manganese to extractable man- ganese is not believed to be significant. First, Chelex-100 is not known to extract manganese directly from the particulate phase. Secondly, for particles that were trapped in the Chelex-100 column during sample loading, the release of particulate manganese to the dissolved phase, so that the particulate manganese might have become available for extraction by Chelex-100, was likely to occur only under sufficiently acidic conditions. Such conditions were found in the analytical scheme only during the elution with $2 \mathrm{~N} \mathrm{HNO}_{3}$. However, the residence time of the $2 \mathrm{~N} \mathrm{HNO}_{3}$ in the column, about $15 \mathrm{~s}$, was short enough so that the leaching of manganese from the particulate phase was not likely to be effective. Thirdly, the fraction of the particles in the samples that might have been trapped in the Chelex-100 column and become available for leaching during elution with $2 \mathrm{~N}$ $\mathrm{HNO}_{3}$ was likely to be small since the particles might have passed through the column with the sample during sample loading or might have been washed out when multiple bed-volumes of DDW and ammonium acetate solution were passed through the column prior to the elution with $2 \mathrm{~N} \mathrm{HNO}_{3}$. Fourthly, other investigators (Hsiung et al., 1998; Hsu, 1998; Hung, personnal communication) have made independent determinations of the concentration of dissolved and/or particulate manga- 
nese at the vicinity of some of our stations in the East China Sea, and found concentrations of dissolved manganese that are similar to the concentrations of extractable manganese reported here. Furthermore, the concentrations of particulate manganese are similar to, or smaller than, the concentrations of dissolved manganese. At a station $\left(25^{\circ} 42^{\prime} \mathrm{N}, 122^{\circ} 12^{\prime} \mathrm{E}\right)$ near our station 5521 on the shelf, Hsu (1998) measured dissolved and particulate manganese in the water column and found that dissolved manganese ranges between 0.9 and $3.3 \mathrm{nM}$ and particulate manganese ranges between 1.0 and $1.6 \mathrm{nM}$ in the subsurface water. As for deep Okinawa Trough water, we will present the comparison of our extractable manganese and dissolved manganese measured by Hsiung et al. (1998) in the following section. All observations tend to suggest that the contribution of particulate manganese to the concentration of extractable manganese was likely to be small so that extractable manganese is thought to be similar to dissolved manganese.

\section{RESULTS AND DISCUSSION}

\subsection{Hydrographic setting of the study area}

Along the transect (figure 1), stations 6115 and 6020 were located on the shelf in the East China Sea Shelf with water depths of around $100 \mathrm{~m}$. Stations 5521 and 5422 were at the shelf break. Stations 542A, 5323 and 5224 were located at the slope and seaward their water depths increased abruptly from 216 to $784 \mathrm{~m}$. Stations 5125, 5030 and 4531 were located in the deep Okinawa Trough where the water depths exceeded $1500 \mathrm{~m}$. The distribution of salinity, temperature, $\sigma_{\theta}$, oxygen, phosphate, and nitrate along the transect are shown in figure 2 and 3. The distributions are similar to those reported previously (Wong et al., 1991; Liu et al., 1992a). The major water masses in the East China Sea are the fresher Changjiang diluted water (also called China Coastal Water), the warm, saline, and nutrient-poor Kuroshio surface water and the cold, saline, oxygen-poor, and nutrient-rich upwelling Kuroshio subsurface water (also known as a mixture of Kuroshio Tropical Water and Kuroshio Intermediate Water (Liu et al., 1992a, 1992b; Chen et al., 1995) and their presence were found in the transect. The water on the shelf (stations 6115 and 6020) was stratified. A strong pycnocline was found at about $70 \mathrm{~m}$. The influence of the Changjiang diluted water was evident above the pycnocline where the freshest water $(S<34.5)$ in the transect was found. However, the Changjiang diluted water itself, which is characterized by a salinity $<33$, was not sampled. The Kuroshio surface water was found in the top $100 \mathrm{~m}$ from station 5224 to station 4531 where salinity and temperature exceeded 34.6 and $25{ }^{\circ} \mathrm{C}$ while the concentrations of nitrate and phosphate were $<0.5$ and $<0.1 \mu \mathrm{M}$, respectively. The upwelling Kuroshio subsurface water was found as a dome of cold $\left(<17^{\circ} \mathrm{C}\right)$, oxygen-poor $(<180 \mu \mathrm{M})$, and nutrient-rich ( $>10 \mu \mathrm{M}$ of nitrate, $>0.7 \mu \mathrm{M}$ of phosphate) water at the shelf edge and upper slope. In the deep Okinawa Trough, the core of the Kuroshio was found as the salinity maximum ( $S>34.8, \sigma_{\theta} \approx 24.5$ ) at about $150 \mathrm{~m}$ (Nitani, 1972) at stations 5125, 5030 and 4531. The North Pacific Intermediate Water, which is also called Kuroshio Intermediate Water in this area (Chen et al., 1995), appeared as the salinity minimum $\left(S>34.3, \sigma_{\theta} \approx 26.5\right)$ (Nitani, $1972)$ at about $600 \mathrm{~m}$ at stations 5125, 5030 and 4531. The concentrations of nitrate and phosphate increased while that of oxygen decreased approximately monotonically with depth in the Okinawa Trough. There was no conspicuous mid-depth nutrient maximum or oxygen minimum.

In the $\theta-S$ relationship (figure 4 ), the broad salinity maximum ( $S \approx 34.86, \theta \approx 21{ }^{\circ} \mathrm{C}, \sigma_{\theta} \approx 24.5$ ) representing the core of the Kuroshio and the salinity minimum ( $S \approx 34.2, \theta \approx 7.5^{\circ} \mathrm{C}, \sigma_{\theta} \approx 26.5$ ) which represented the North Pacific Intermediate Water were prominent features in the deep Okinawa Trough at station 4531. In the shallower waters at temperatures above $15{ }^{\circ} \mathrm{C}$, the $\theta-\mathrm{S}$ relationship remained almost the same from station 4531 to station 5030. Shelf-ward of station 5030, as the influence of the fresher water from the shelf became significant, the salinity maximum diminished significantly and progressively, and the $\theta-S$ curves fanned out systematically. All the $\theta-\mathrm{S}$ curves converged to a common point at about 12 to $15^{\circ} \mathrm{C}$ where the source of the upwelling Kuroshio subsurface water was found (Wong et al., 1991). In the deep water, the $\theta-S$ relationships were almost identical at the three stations in the deep Okinawa Trough. Between stations 5125 and 5224 , there was an abrupt erosion of the salinity minimum suggesting a change in the origin of the intermediate water from a branch from the South China Sea to a branch from the West Philippine Sea (Chen and Wang, 1998). 

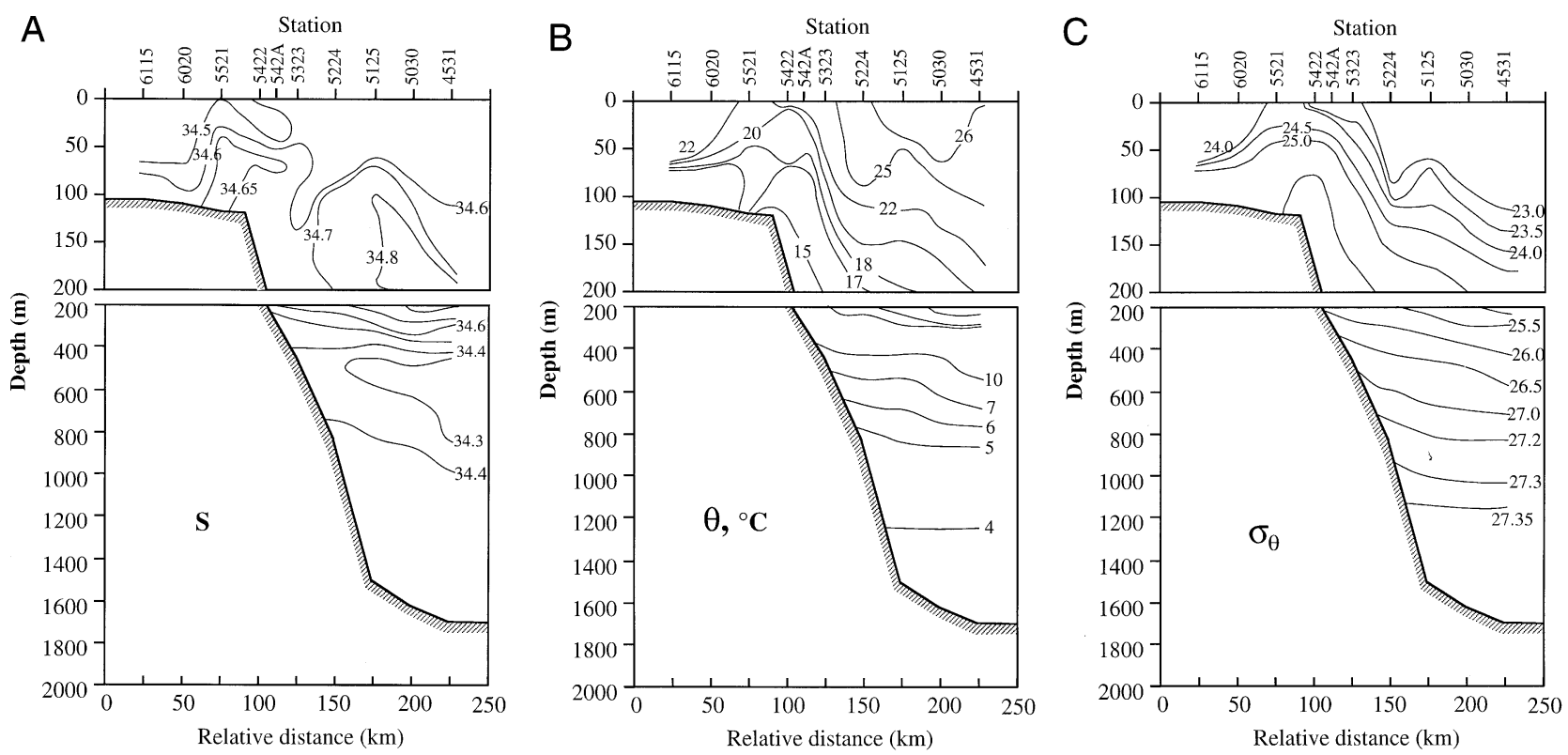

Figure 2. The distribution of salinity (A), potential temperature (B), and $\sigma_{\theta}$ along the transect (C).

\subsection{Extractable manganese in the East China Sea Shelf and its adjoining waters in the Okinawa Trough}

The distribution of extractable manganese along the transect is shown in figure 5. In the top $200 \mathrm{~m}$ of the water column, a tongue of manganese-rich water $(>3 \mathrm{nM})$, extending from the shelf into the Okinawa Trough, was clearly present. The enrichment of manganese in shelf waters as a result of riverine input has been welldocumented (Toyota, 1988; Tappin et al., 1993; Minakawa et al., 1996). The East China Sea Shelf-Huang
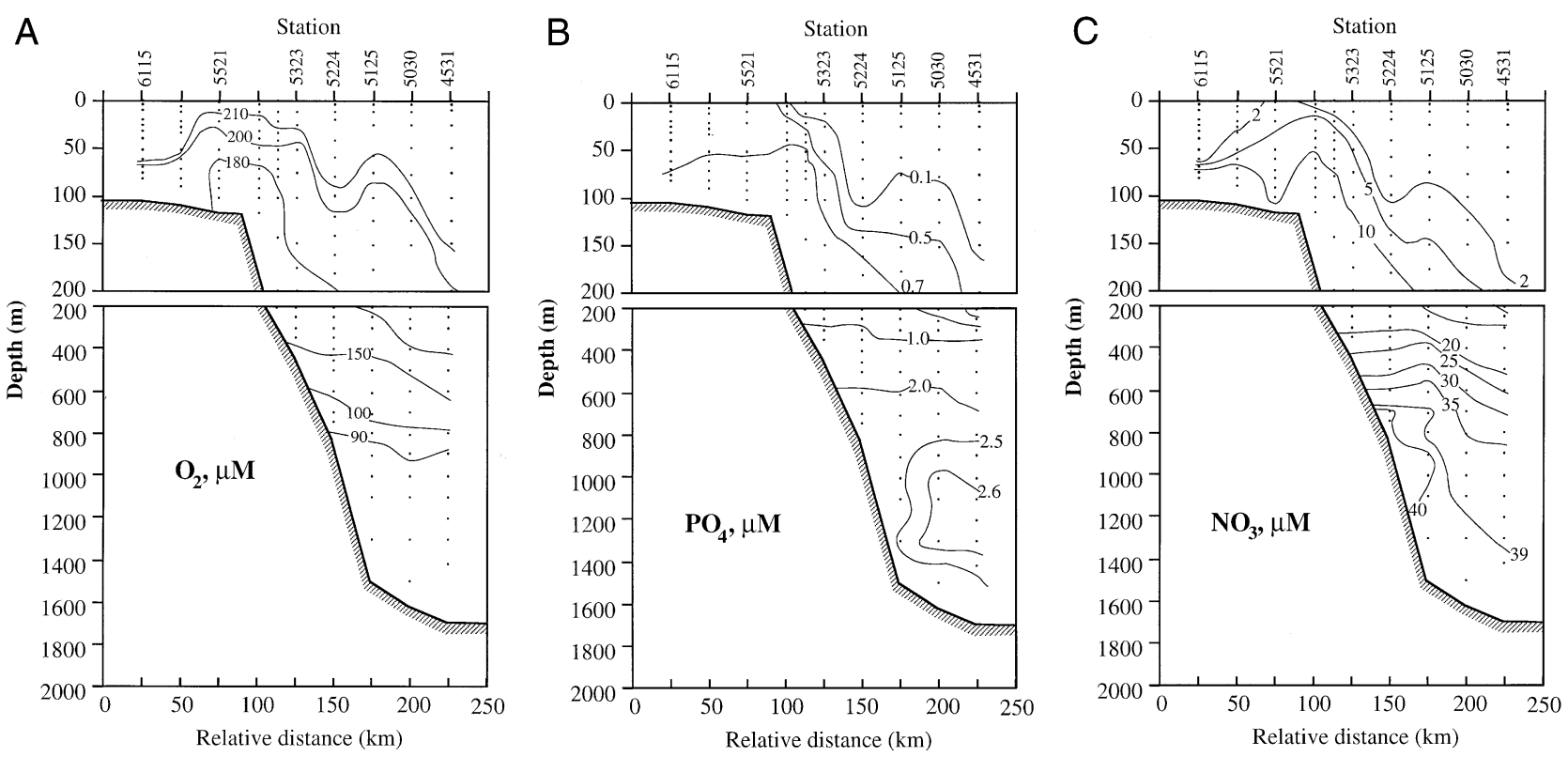

Figure 3. The distribution of oxygen (A), phosphate (B), and nitrate along the transect (C). 

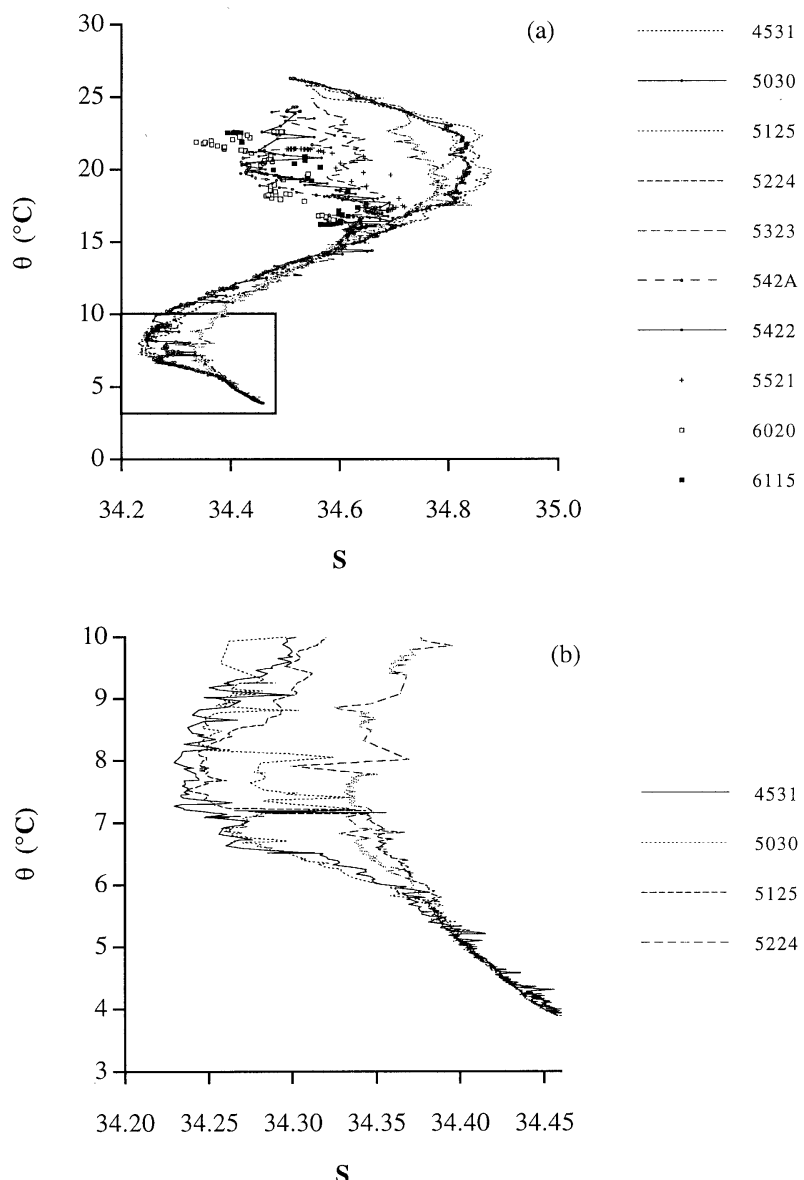

Figure 4. The relationship between potential temperature and salinity in the entire water column (a), and, in the deep water $\left(\tau<10^{\circ} \mathrm{C}\right)$ at the different stations (b).

Hai-Bo Hai system is no exception. The waters of the Changjiang and Huanghe, the primary riverine source of material to the system, are enriched in manganese. The concentrations of dissolved manganese have been reported to be 18 and $25 \mathrm{nM}$ respectively (Edmond et al., 1985; Zhang, 1995) .Minakawa et al. (1996) determined the distribution of total dissolvable manganese in the East China Sea Shelf north of our study area at locations mostly shoreward of our stations. (It should be noted that in the analytical scheme used by Minakawa et al. (1996) unfiltered seawater samples were acidified to $\mathrm{pH}<2$ and stored for an unspecified period of time before they were analyzed for manganese in a shore-based laboratory. Thus, while extractable manganese is close to dissolved manganese, total dissolvable manganese includes dissolved manganese plus an unspecified fraction of particu-

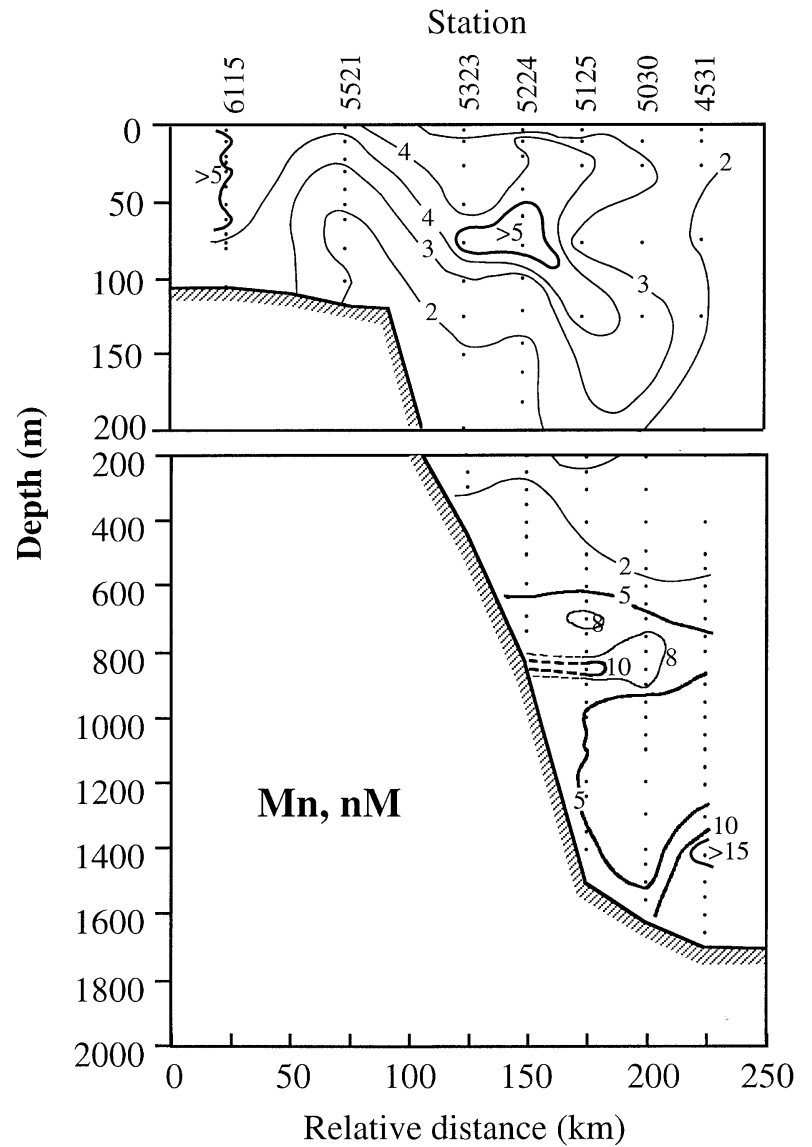

Figure 5. The distribution of extractable manganese along the transect.

late manganese. If there is a significant contribution from particulate manganese, the concentration of total dissolvable manganese will be higher than the corresponding concentration of extractable manganese.) They reported that the concentration of total dissolvable manganese increased shoreward reaching concentrations exceeding $110 \mathrm{nM}$ near the mouth of the Changjiang. The higher concentrations of total dissolvable manganese near the mouth of the Changjiang, relative to the concentration of dissolved manganese in the Changjiang, could have originated from the inclusion of some fraction of particulate manganese in the determination of total dissolvable manganese, from the desorption of manganese from suspended particles (Edmond et al., 1985) and/or the remobilization of particulate manganese in the coastal sediments (Zhang, 1995). In this study, at the most 
shoreward station in the mid-shelf (station 6115), the distribution of extractable manganese above the pycnocline was rather uniform and the concentrations (4 to $6 \mathrm{nM}$ ) were among the highest found in the top $100 \mathrm{~m}$ along the entire transect. In contrast, the Kuroshio surface water in the deep Okinawa Trough was manganese-poor ( 2 to $3 \mathrm{nM}$ ). These concentrations are comparable to those reported by Minakawa et al. (1996) in the Kuroshio adjoining the East China Sea Shelf and by Toyota (1988) in the Kuroshio off Japan. However, they are still higher than the concentrations $(\approx 1 \mathrm{nM})$ in the central gyre of the North Pacific (Landing and Bruland, 1980). This apparent shoreward increase in the concentration of extractable manganese is consistent with the trend observed in the distribution of total dissolvable manganese (Minakawa et al., 1996). The concentration of extractable manganese in the core of the Kuroshio was about 3 to $4 \mathrm{nM}$. The upwelling Kuroshio subsurface water appeared as a dome of manganese-poor $(<2 \mathrm{nM})$ water at the shelf edge which protruded into the tongue of manganese-rich water from the shelf. Thus, during upwelling and frontal exchanges, manganese-poor water is imported into the East China Sea while manganese-rich water is exported to the Kuroshio. While this general description of the exchange of extractable manganese between the East China Sea and the Kuroshio is well supported, the specific distribution of extractable manganese in the frontal zone is likely to be variable since the intensity of upwelling and frontal exchanges may vary spatially and temporally along the shelf break and upper slope. Although our study area was situated downwind from the atmospheric transport of the Central Asian dust (Duce et al., 1991), there was no evidence that indicated that atmospheric deposition was a significant factor in determining the distribution of dissolved manganese even in the deep Okinawa Trough which is at some distance away from the influence of the riverine input from land. No prominent surface manganese maximum was found at any of the stations. In fact, a surface minimum was frequently found seaward of the shelf edge as the surface water was underlaid by the manganese-rich tongue of water from the shelf.

\subsection{The geochemical dynamics of extractable manganese in the East China Sea Shelf-Huang Hai-Bo Hai system}

Since the East China Sea Shelf exchanges freely with the Huang Hai and Bo Hai, these three seas are treated as a

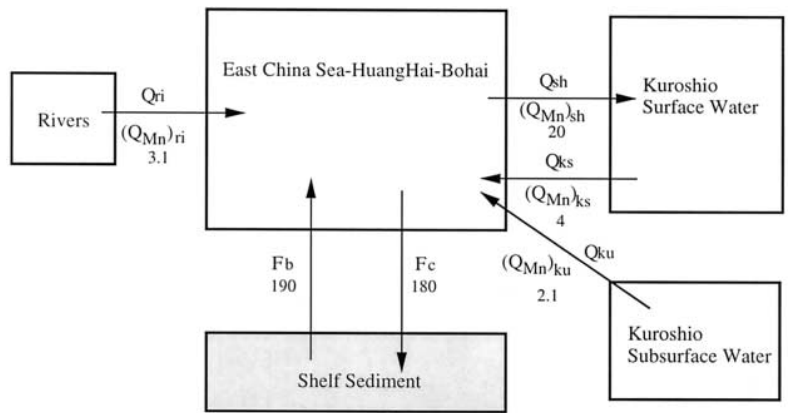

Figure 6. A box model of the East China Sea-Huang Hai-Bo Hai system. Values are given in $10^{7}$ mole $\cdot y e r^{-1}$.

single system. The geochemical dynamics of extractable manganese in this system can be estimated with a box-model calculation (figure 6). Extractable manganese is added to the system through riverine input, upwelling of the Kuroshio subsurface water, exchange with the Kuroshio surface water, and the diffusion of manganese from the sediments as a result of diagenetic remobilization of particulate manganese in the sediments. The atmospheric deposition of manganese is assumed to be in the particulate form which is not readily solubilized within the water column. Extractable manganese is removed from the system by its movement to the particulate phase and by the export of shelf water to the Kuroshio and to the Japan Sea. Thus, if extractable manganese in the system is at a steady state, its mass balance in the East China Sea Shelf-Huang Hai-Bo Hai system is:

$$
\begin{aligned}
& \left(Q_{\mathrm{Mn}}\right)_{\mathrm{ri}}+\left(Q_{\mathrm{Mn}}\right)_{\mathrm{ks}}+\left(Q_{\mathrm{Mn}}\right)_{\mathrm{ku}}+F_{\mathrm{b}}=\left(Q_{\mathrm{Mn}}\right)_{\mathrm{sh}}+F_{\mathrm{c}} \\
& \text { and }\left(Q_{\mathrm{Mn}}\right)_{\mathrm{ks}}=Q_{\mathrm{ks}} \cdot M n_{\mathrm{ks}},\left(Q_{\mathrm{Mn}}\right)_{\mathrm{ku}}=Q_{\mathrm{ku}} \cdot M n_{\mathrm{ku}}, \\
& \left(Q_{\mathrm{Mn}}\right)_{\mathrm{sh}}=Q_{\mathrm{sh}} M n_{\mathrm{sh}}
\end{aligned}
$$

where $\left(Q_{\mathrm{Mn}}\right)$ is the flux of extractable manganese, $Q$ is the flux of water and $M n$ is the concentration of extractable manganese. The subscripts $r i, k s, k u$ and $s h$ denote the incoming river water, the intruding Kuroshio surface water, the upwelling Kuroshio subsurface water, and the outgoing East China Sea Shelf water. $F_{\mathrm{b}}$ is the benthic flux of manganese added to the system from the sediments, and $F_{\mathrm{c}}$ is the removal of manganese to the particulate phase in the water column.

By considering the mass balances of water and salt, Chen (1996) estimated that the total intrusion of Kuroshio water onto the East China Sea Shelf is $3.3 \times 10^{4} \mathrm{~km}^{3} \cdot$ year $^{-1}$ and the inputs as Kuroshio surface 
water and upwelling Kuroshio subsurface water are $1.6 \times$ $10^{4}$ and $1.7 \times 10^{4} \mathrm{~km}^{3} \cdot$ year $^{-1}$ respectively, so that the ratio of $Q_{\mathrm{ks}}$ to $Q_{\mathrm{ku}}$ is about $1: 1$. By considering the mass balance of $\delta^{18} \mathrm{O}$, in addition to those of water and salt, in the East China Sea Shelf-Huang Hai-Bo Hai system, Sheu et al. (1999) arrived at virtually identical values so that $Q_{\mathrm{ks}}, Q_{\mathrm{ku}}$ and $Q_{\mathrm{sh}}$ are 1.5, 1.5, and $3.1 \times 10^{4} \mathrm{~km}^{3} \cdot$ year $^{-1}$ respectively. The values of Sheu et al. (1999) have been adopted in this modelling exercise. The seaward fluxes of dissolved manganese to the system through the Changjiang and the Huanghe estuaries are 2.8 and $0.3 \times 10^{7}{\text { mole } \cdot y e a r^{-1}}$ (Zhang, 1995). Thus, $\left(Q_{\mathrm{Mn}}\right)_{\mathrm{ri}}$ is $3.1 \times 10^{7}$ mole.year ${ }^{-1}$. The salinity and temperature of the Kuroshio surface water have been estimated to be 34.4 to 34.7 and 24.5 to $29.0^{\circ} \mathrm{C}$ respectively ( $\mathrm{Li}, 1994$; Chen, 1996). The average concentration of extractable manganese in all the samples within these salinity and temperature ranges in the surface waters at stations 5125,5130 and 4531 in the deep Okinawa Trough is $2.7 \pm 0.8 \mathrm{nM}$. By using this value for $M n_{\mathrm{ks}},\left(Q_{\mathrm{Mn}}\right)_{\mathrm{ks}}$ was estimated to be $4( \pm 1) \times 10^{7}$ mole $\cdot$ year $^{-1}$.

Wong et al. (1991) estimated that the upwelling Kuroshio subsurface water originates from a depth of about $300 \mathrm{~m}$ with a temperature of 12 to $14{ }^{\circ} \mathrm{C}$. The salinity of this water has been estimated to be 34.6 (Li, 1994) and 34.3 to 34.8 (Chen, 1996). The average concentration of extractable manganese in all samples from the deep Okinawa Trough that met these criteria was $1.4 \pm 0.4 \mathrm{nM}$, and this value was used as $M n_{\mathrm{ku}}$. The corresponding value for $\left(Q_{\mathrm{Mn}}\right)_{\mathrm{ku}}$ is then $2.1( \pm 0.6) \times 10^{7}$ mole year $^{-1}$.

Li (1994) suggested that the salinity of the shelf water that is exported from the East China Sea Shelf is $33 \pm 0.2$. Chen (1996) estimated that the salinity is 33.1 during the wet season between May and October and 33.8 during the dry season between November and April. Samples with such low salinities were not collected in this study. The freshest samples were found in the surface waters at station 6115 and their salinity was about 34.4. Minakawa et al. (1996) reported that, while the concentration of total dissolvable manganese in the surface waters of the East China Sea Shelf increases with decreasing salinity, between salinities of 32.5 and 35 , the concentration changes, ranging between 3.9 and $6.9 \mathrm{nM}$, are small. Within this salinity range, the concentrations of extractable manganese found in this study fall along the same trend such that the average concentration of total dissolvable manganese in surface waters with salinities between 34 and 35 was $5 \pm 1 \mathrm{nM}$ (Minakawa et al., 1996), while the average concentration of extractable manganese in the samples with salinities of 34.4 was also $5 \pm 1 \mathrm{nM}$. Apparently, the particulate load and thus particulate manganese in the surface waters in the open East China Sea Shelf and the Kuroshio may be small enough so that the differences between total dissolvable manganese and extractable manganese may become insignificant. At salinities between 32.5 and 33.5, the average concentration of total dissolvable manganese in the surface samples collected by Minakawa et al. (1996) was $6.5 \pm 0.9 \mathrm{nM}$. This value is used as $\mathrm{Mn}_{\mathrm{sh}}$ so that $\left(Q_{\mathrm{Mn}}\right)_{\mathrm{sh}}$ may then be estimated to be $20( \pm 3) \times 10^{7}$ mole.year ${ }^{-1}$. Nozaki et al. (1991) reported that the removal residence times $\left(\tau_{\mathrm{c}}\right)$ of ${ }^{210} \mathrm{~Pb}$ from the dissolved phase to the particulate phase in the East China Sea Shelf ranged from 0.5 to five months with a most likely value of two months. Assuming that the removal residence time of extractable manganese in the system is similar to that of ${ }^{210} \mathrm{~Pb}$, then:

$$
F_{c}=V \cdot M n_{\mathrm{sh}} / \tau_{c}
$$

where $V$ is the volume of the system which is about $4.5 \times 10^{4} \mathrm{~km}^{3}$ (Nozaki et al., 1991). Thus, by allowing for an uncertainty of $\pm 0.9 \mathrm{nM}$ in $\mathrm{Mn}_{\mathrm{sh}}$ and $\pm 50 \%$ in $\tau_{c}, F_{c}$ may be calculated to be $180( \pm 110) \times 10^{7}$ mole year $^{-1}$. Since $\left(Q_{\mathrm{Mn}}\right)_{\mathrm{ri}},\left(Q_{\mathrm{Mn}}\right)_{\mathrm{ks}},\left(Q_{\mathrm{Mn}}\right)_{\mathrm{ku}},\left(Q_{\mathrm{Mn}}\right)_{\mathrm{sh}}$ and $F_{\mathrm{c}}$ are known or can be estimated, $F_{\mathrm{b}}$ is the remaining unknown and it can be estimated from the mass-balance equation to be $190( \pm 120) \times 10^{7}$ mole $\cdot$ year $^{-1}$.

The input parameters and the results of the model calculation are shown in table I. The input of dissolved/ extractable manganese from the rivers, the intrusion of the Kuroshio surface water and the upwelling of the Kuroshio subsurface water are all of similar magnitude. The sum total of the inputs from the Kuroshio exceeds the riverine input. However, all these fluxes are about an order of magnitude smaller than the export of manganese from the shelf $\left[\left(Q_{\mathrm{Mn}}\right)_{\mathrm{sh}}, 20( \pm 3) \times 10^{7}\right.$ mole year $\left.^{-1}\right]$. Furthermore, there is a net export of extractable manganese from the East China Sea Shelf, $\left(Q_{\mathrm{Mn}}\right)_{\mathrm{ex}}$, since:

$$
\begin{array}{r}
\left(Q_{\mathrm{Mn}}\right)_{\mathrm{ex}}=\left(Q_{\mathrm{Mn}}\right)_{\mathrm{sh}}-\left[\left(Q_{\mathrm{Mn}}\right)_{\mathrm{ks}}+\left(Q_{\mathrm{Mn}}\right)_{\mathrm{ku}}\right]=14( \pm \\
5) \times 10^{7} \mathrm{~mole} \cdot \text { year }^{-1}
\end{array}
$$

Thus, the East China Sea Shelf is a net source of extractable manganese to its adjoining waters. This net export of extractable manganese is about five times the input of dissolved manganese from the rivers. The amount in excess of the riverine input is $11 \times 10^{7}$ mole $\cdot y e a r^{-1}$. A logical mechanism for support- 
Table 1. Input parameters and results of the box-model calculation of extractable manganese

\begin{tabular}{|c|c|c|c|c|c|}
\hline & Salinity & $\begin{array}{l}\text { Temperature } \\
\left({ }^{\circ} \mathrm{C}\right)\end{array}$ & $\begin{array}{l}\text { Water flux } \\
\left(\times 10^{3} \mathrm{~km}^{3} \cdot \mathrm{year}^{-1}\right)\end{array}$ & $\begin{array}{l}\mathrm{Mn} \\
(\mathrm{nM})\end{array}$ & $\begin{array}{l}\text { Mn flux } \\
\left(\times 10^{7} \text { mole } \text { year }^{-1)}\right.\end{array}$ \\
\hline Riverine Input (ri) & 0.18 & - & 1.1 & - & 3.1 \\
\hline Incoming Kuroshio surface water (ks) & $34.4-34.7$ & $24.5-29$ & 14.6 & 2.7 & 4 \\
\hline Incoming upwelling Kuroshio subsurface water $(\mathrm{ku})$ & $34.3-34.8$ & $12-14$ & 14.8 & 1.4 & 2 \\
\hline Outgoing shelf water (sh) & $32.5-33.5$ & - & 30.7 & 6.5 & 20 \\
\hline Removal to particulate phase $\left(F_{\mathrm{c}}\right)$ & & & & & 180 \\
\hline Benthic flux $\left(F_{\mathrm{b}}\right)$ & & & & & 190 \\
\hline Net export from shelf $\left(F_{\mathrm{ex}}\right)$ & & & & & 4 \\
\hline
\end{tabular}

ing this excess exported extractable manganese is the diagenetic remobilization of particulate manganese from the rivers in the sediments in the East China Sea Shelf-Huang Hai-Bo Hai system and this source of manganese appears as part of the benthic flux. Zhang (1995) reported that the major rivers that drain into the East China Sea Shelf-Huang Hai-Bo Hai system, namely, the Huanghe, the Changjiang and the Daliaohe, deliver a total of $2.6 \times 10^{10}$ mole-year ${ }^{-1}$ of particulate manganese to the system. Thus, the excess export of manganese may be sustained by mobilizing only about $0.4 \%$ of this particulate load from the rivers. $F_{\mathrm{b}}$ and $F_{\mathrm{c}}$ are approximately equal to each other and are almost an order of magnitude larger than $\left(Q_{\mathrm{Mn}}\right)_{\mathrm{sh}}$ and $\left(Q_{\mathrm{Mn}}\right)_{\mathrm{ex}}$ and more than two orders of magnitude larger than the other fluxes. Thus, the manganese cycle in this shelf-sea system is dominated by exchanges between the water column and the underlying sediments and these exchanges constitute an approximately closed cycle. While there are considerable uncertainties in the absolute values of the fluxes, the general picture of the cycling of manganese in this shelf-sea system should stay relatively robust since the differences among the major fluxes approach orders of magnitude and exceed the uncertainties by far. Based on the distribution of total dissolvable manganese, Minakawa et al. (1996) arrived at similar conclusions.

\subsection{Extractable manganese in the deep waters of the Okinawa Trough}

The isopleth of $\sigma_{\theta}=26.5$ which represents the North Pacific Intermediate Water in the Okinawa Trough was located at about $600 \mathrm{~m}$ (figure 2) and it coincided approximately with the isopleth of extractable manganese of $2 \mathrm{nM}$ (figure 5). Below the Intermediate Water, the concentration of oxygen decreased steadily with depth, dropping below $100 \mu \mathrm{M}$ below at about $800 \mathrm{~m}$. Concomitantly, higher concentrations of extractable manganese ( 3 to $15 \mathrm{nM}$ ) were found in these deep and bottom waters. In the open oceans, elevated concentrations of dissolved manganese have been consistently found in the oxygen-minimum layer when the concentration of oxygen drops below $100 \mu \mathrm{M}$ (Klinkhammer and Bender, 1980; Martin and Knauer, 1982, 1984; Martin et al., 1985; Saager et al., 1989). Apparently, under these lower concentrations of oxygen, the reduction of manganese oxides and/or the dissolution of settling particles in the water column and/or in the underlying sediments to form $\mathrm{Mn}^{2+}$, coupled with the slow rate of oxidation of $\mathrm{Mn}^{2+}$ (Yeats and Strain, 1990), may lead to the accumulation of dissolved manganese in the water column. The generally elevated concentrations of extractable manganese in the deep Okinawa Trough might have been caused by similar processes.

Superimposed on these generally elevated concentrations of extractable manganese, there were two distinct layers of especially manganese-rich water in the deep Okinawa Trough. One was situated at about 700 to $1000 \mathrm{~m}\left(S \approx 34.4, \theta \approx 5.2\right.$ to $5.7^{\circ} \mathrm{C}, \sigma_{\theta} \approx 27.1$ to 27.2$)$ where concentrations exceeding $8 \mathrm{nM}$ were found. It coincided approximately with the bottom of the pycnocline (figure 7) and with a slight inflexion point in the $\theta-\mathrm{S}$ relationship (figure $4 b$ ) so that it might represent a unique water mass. The source of this excess manganese is presently uncertain. The occurrence of elevated concentrations of extractable manganese (Wei et al., 1991), total dissolvable manganese (Minakawa et al., 1996), and dissolved manganese (Hsiung et al., 1998) at similar concentrations and depths in this part of the Okinawa Trough have been reported by other investigators. Thus, while Wei et al. (1991) have reported that the concentrations of suspended particles may also be high at 

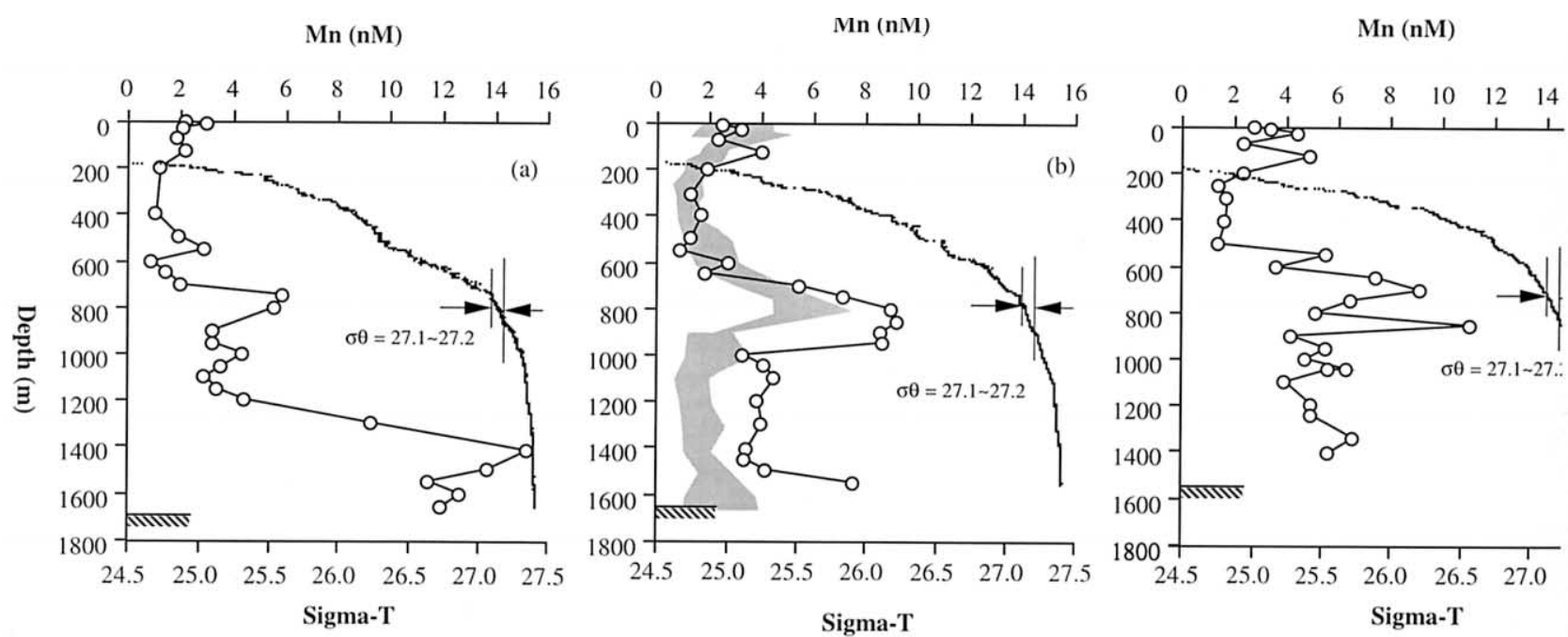

Figure 7. The depth profiles of extractable manganese and $\sigma_{\theta}$ at station 4531 (a), 5030 (b), and 5125 (c) in the deep Okinawa Trough. Shaded area in (b) represents the range of the dissolved-manganese concentration near $123^{\circ} 13^{\prime} \mathrm{E}, 2^{\circ} 06^{\prime} \mathrm{N}$ (From: Hsiung et al., 1998).

approximately the same depth as this manganese-rich layer of water, this enrichment of extractable manganese cannot be explained by the possible inclusion of particulate manganese in the determination of extractable manganese alone. Lin et al. (1992) reported that a band of organic-rich fine-grain sediment lines the lower-shelf upper slope of the East China Sea Shelf which forms the northern flank of the Okinawa Trough (figure 1) at 500 to $1000 \mathrm{~m}$, about the same depth range of this layer of manganese-rich water. In such a sedimentary environment, there might have been a preferential diagenetic remobilization of manganese in the sediments and an accompanying diffusion of manganese from the sediments into the bottom water. A lateral transport of this manganese along an isopycnal surface may then give rise to this manganese-rich layer of water. Since this manganese-rich layer was situated at the bottom of the pycnocline, another possible source of the manganese is the trapping of particles on a pycnocline coupled with a release of manganese from these particles by their dissolution.

The other manganese-rich layer of water was found at 1300 to $1500 \mathrm{~m}$. It was especially well defined at station 4531 (figure $7 a$ ). The maximum concentration was not found at the bottom but rather at about $250 \mathrm{~m}$ above the bottom. At a nearby location approximately $15 \mathrm{~km}$ to the northeast of our station 5030, around the same depth, Hsiung et al. (1998) reported elevated concentrations of dissolved manganese of similar magnitude. Superimposed on figure $7 b$, the range of dissolved manganese measured by Hsiung et al. (1998) is shown as shaded area. Note the similarity between our extractable manganese and dissolved manganese profiles. Thus, again, while particulate manganese concentrations are usually higher in bottom waters, the inclusion of particulate manganese in the determination of extractable manganese alone is not sufficient for explaining these elevated concentrations. This extractable manganese-rich layer of water coincided with slightly lower concentrations of phosphate that were not accompanied by correspondingly lower concentrations of nitrate (figure 3). Hydrothermal activities can result in seawater which is enriched in dissolved manganese (Bender et al., 1977; Weiss, 1977; Klinkhammer and Bender, 1980; Klinkhammer et al., 1985; Ishibashi et al., 1988) and impoverished in phosphate (Wheat et al., 1996). In fact, manganese has been used as a tracer of hydrothermal plumes (Klinkhammer et al., 1985; Klinkhammer and Hudson, 1986; Cowen et al., 1990; Coale et al., 1991). This would be an intriguing possible contributor to the enrichment of manganese in the bottom water given that hydrothermal activities are known to occur in the Okinawa Trough (Lallemand et al., 1997) and that manganese-rich hydrothermal fluid has been found (Ishibashi et al., 1988). Nonetheless, our sampling sites were at some distance away from the reported hydrothermal vent field. This present data set is still too limited to make a definitive claim. 


\section{CONCLUSION}

During mixing between the East China Sea Shelf and its adjoining waters, manganese-poor water $(<3 \mathrm{nM})$ is imported into the East China Sea Shelf by upwelling and frontal exchanges, while manganese-rich water $(>3 \mathrm{nM})$ is exported out of the Shelf. Thus, the East China Sea Shelf is a net source of dissolved manganese and it exports $14 \times 10^{7}$ mole $\cdot y e{ }^{-1}$ of extractable manganese to its adjoining waters. Nonetheless, the cycling of extractable manganese within the East China Sea Shelf-Huang Hai-Bo Hai system is dominated by exchanges between the water column and the underlying sediments. These fluxes are about an order of magnitude larger than the net export of dissolved manganese from the system and they form an almost closed cycle. The deep water $(>600 \mathrm{~m})$ in the Okinawa Trough is oxgyen-poor $(<100 \mu \mathrm{M})$ and manganese-rich $(>3 \mathrm{nM})$. Within these generally elevated concentrations, two distinct layers of manganeserich water $(>8 \mathrm{nM})$ were found at 700 to $1000 \mathrm{~m}$ and 1300 to $1500 \mathrm{~m}$. The depth of the former coincides with that of a band of organic-rich fine-grain sediment along the lower shelf and upper slope. The depth of the latter coincides with that of known hydrothermal vent fields in the Okinawa Trough. Nonetheless, the origin of these plumes cannot yet be established with certainty.

\section{Acknowledgements}

This paper is excerpted from the M.S. thesis of S.-J. Sun. The authors are grateful to Drs. K.-K. Liu, Su-Cheng Pai, and Saulwood Lin for their inputs, and to Dr T.-M. Hsiung for providing their dissolved-manganese data. The manuscript benefits from the comments by Dr Chih-An Huh and three anonymous reviewers. This work was supported in part by the National Science Council (Taiwan) under grants number NSC-88-2611-M-002-007-K2 to Wei, and, by the National Science Foundation under grant number OCE-9301298 and INT-9515521 to Wong. This is Contribution No. 28 of the National Center for Ocean Research (NCOR) of the National Science Council of Taiwan.

\section{REFERENCES}

Bender, M.L., Klinkhammer, G.P., Spencer, D.W., 1977. Manganese in seawater and the marine manganese balance. Deep-Sea Res. 24, 799-812.
Bruland, K.W., Franks, R.P., 1983. Mn, Ni, Cu, $\mathrm{Zn}$ and $\mathrm{Cd}$ in the Western North Atlantic. In: Wong, C.S., Boyle, E., Bruland, K.W., Burton, J.D., Goldberg, E.D. (Eds.), Trace metals in seawater. Plenum Press, New York, pp. 395-414.

Carpenter, J.M., 1965. The Chesapeake Bay Institute technique for the Winkler dissolved oxygen method. Limnol. Oceanogr. 10, 141-143.

Chen, C.T.A., 1996. The Kuroshio intermediate water is the major source of nutrients on the East China Sea continental shelf. Oceanol. Acta 19, 523-527.

Chen, C.T.A., Rui, R., Pai, S.C., Liu, C.T., Wong, G.T.F., 1995. Exchange of water masses between the East China Sea and the Kuroshio off northeastern Taiwan. Cont. Shelf Res. 15, 19-39.

Chen, C.T.A., Wang, S.L., 1998. Influence of intermediate water in the western Okinawa Trough by the outflow from the South China Sea. J. Geophys. Res. 103, 12683-12688.

Coale, K.H., Chin, C.S., Massoth, G.F., Johnson, K.S., Baker, E.T., 1991. In situ chemical mapping of dissolved iron and manganese in hydrothermal plumes. Nature 352, 325-328.

Cowen, J.P., Massoth, G.J., Feely, R.A., 1990. Scavenging rates of dissolved manganese in a hydrothermal vent plume. Deep-Sea Res. 37, 1619-1637.

Donat, J.R., Bruland, K.W., 1995. Trace elements in the oceans. In: Salber, B., Steinnes, E. (Eds.), Trace elements in natural waters. CRC Press, Boca Raton, FL, pp. 247-281.

Duce, R.A., Liss, P.S., Merrill, J.T., Atlas, E.L., Buat-Menard, P., Hicks, B.B., Miller, J.M., Prospero, J.M., Arimoto, R., Church, T.M., Ellis, W., Galloway, J.N., Hansen, L., Jickells, T.D., Knap, A.H., Rheinhardt, K.H., Schneider, B., Sudine, A., Tokos, J.J., Tsunogai, S., Wollast, R., Zhou, M., 1991. The atmospheric input of trace species to the world ocean. Global Biogeochem. Cycles 5, 193-259.

Edmond, J.M., Spivack, A., Grant, B.C., Hu, M.-H., Chen, Z., Chen, S., Zeng, X., 1985. Chemical dynamics of the Changjiang estuary. Cont. Shelf Res. 4, 17-36.

Fang, T.S., Lin, S.F., Liu, K.K., 1990. Precise measurement of salinity using Autosal salinometer: (1) Laboratory tests. Acta Oceanogr. Taiwaninca 25, 114-121.

Heggie, D., Klinkhammer, G., Cullen, D., 1987. Manganese and copper fluxes from continental margin sediments. Geochim. Cosmochim. Acta 51, 1059-1070.

Hsiung, T.M., Gong, G.C., Pai, S.C., 1998. A persistent mid-depth dissolved manganese maximum in the southern Okinawa Trough. Terr. Atmos. Ocean. Sci. 9, 119-125.

Hsu, S.C., 1998. Sources and transport of sediments and trace metal geochemistry in the water column off northeastern Taiwan, $\mathrm{PhD}$ thesis. National Taiwan University, Taiwan.

Ishibashi, J.-I., Gamo, T., Sakai, H., Nojiri, Y., Igarashi, G., Shitashima, K., Tsubota, H., 1988. Geochemical evidence for hydrothermal activity in the Okinawa Trough. Geochem. J. 22, 107-114.

Klinkhammer, G.P., Bender, M.L., 1980. The distribution of manganese in the Pacific Ocean. Earth Planet. Sci. Lett. 46, 361-384.

Klinkhammer, G.P., Chin, C.S., Wilson, C., Rudnicki, M.D., German, C.R., 1997. Distributions of dissolved manganese and fluorescent 
dissolved organic matter in the Columbia River estuary and plume as determined by in situ measurement. Mar. Chem. 56, 1-14.

Klinkhammer, G.P., Hudson, A., 1986. Dispersal patterns for hydrothermal plumes in the South Pacific using manganese as a tracer. Earth Planet. Sci. Lett. 79, 241-249.

Klinkhammer, G.P., Rona, Greaves, M., Elderfield, H., 1985. Hydrothermal manganese plumes in the Mid-Atlantic Ridge rift valley. Nature 314, 727-731.

Lallemand, S.E., Liu, C.S.ACT Scientific Party, 1997. Swath bathymetry reveals active arc-continent collision near Taiwan. EOS 78, 173-175.

Landing, W.M., Bruland, K.W., 1980. Manganese in the North Pacific. Earth Planet. Sci. Lett. 49, 45-56.

Li, Y.H., 1994. Material exchange between the East China Sea and the Kuroshio Current. Terr. Atm. Oceanic Sci. 5, 625-631.

Lin, S., Liu, K.K., Chen, P., Chang, F.Y., 1992. Distribution of organic carbon in the KEEP area continental margin sediments. Terr. Atmos. Ocean. Sci. 3, 365-378.

Liu, K.K., Gong, G.C., Shyu, C.Z., Pai, S.C., Wei, C.L., Chao, S.Y., 1992a. Response of Kuroshio upwelling to the onset of the Northeast monsoon in the sea north of Taiwan: observation and a numerical simulation. J. Geophys. Res. 97, 12511-12526.

Liu, K.K., Gong, G.C., Lin, S., Zhyu, C.Z., Yang, C.Y., Wei, C.L., Pai, S.C., Wu, C.K., 1992b. The year-round upwelling at the shelf break near the northern tip of Taiwan as evidenced by chemical hydrography. Terr. Atmos. Ocean. Sci. 3, 234-276.

Martin, J.H., Knauer, G.A., 1980. Manganese cycling in Northeast Pacific waters. Earth Planet. Sci. Lett. 51, 266-274.

Martin, J.H., Knauer, G.A., 1982. Manganese cycling in northeast Pacific equatorial waters. J. Mar. Res. 40, 1213-1225.

Martin, J.H., Knauer, G.A., 1984. VERTEX: manganese transport through oxygen minima. Earth Planet. Sci. Lett. 67, 35-47.

Martin, J.H., Knauer, G.A., Broenkow, W.W., 1985. VERTEX: the lateral transport of manganese in the northeast Pacific. Deep-Sea Res. 32, 1405-1427.

Minakawa, M., Noriki, S., Tsunogai, S., 1996. Manganese in the East China Sea and the Yellow Sea. Geochem. J. 30, 41-55.

Mottl, M.J., Sansone, F.J., Wheat, C.G., Resing, J.A., Baker, E.T., Lupton, J.E., 1995. Manganese and methane in hydrothermal plumes along the East Pacific Rise, $8^{\circ} 40^{\prime}$ to $11^{\circ} 50^{\prime}$ N. Geochim. Cosmochim. Acta 59, 4147-4165.

Murphy, J., Riley, J.P., 1962. A modified single solution method for the determination of phosphate in natural waters. Anal. Chim. Acta 27, 31-36.

Nitani, H., 1972. Beginning of the Kuroshio. In: Kuroshio, H., Stommel, K., Yoshida (Eds.), Kuroshio. University of Washington Press, Seattle, WA, pp. 95-128.

Nozaki, Y., Tsubota, H., Kasemsupaya, V., Yashima, M., Ikuta, N., 1991. Residence times of surface water and particle-reactive ${ }^{210} \mathrm{~Pb}$ and ${ }^{210} \mathrm{Po}$ in the East China and Yellow seas. Geochim. Cosmochim. Acta 55, 1265-1272.
Pai, S.C., Yang, C.C., Riley, J.P., 1990a. Formation kinetics of the pink azo dye in the determination of nitrite in natural waters. Anal. Chim. Acta 232, 349-354.

Pai, S.C., Fang, T.H., Chen, C.T.A., Jeng, K.L., 1990b. A low contamination Chelex-100 technique for shipboard preconcentration of heavy metals in seawater. Mar. Chem. 29, 295-306.

Pai, S.C., Gong, G.C., Liu, K.K., 1993. Determination of dissolved oxygen in seawater based on direct spectrophotometry of total iodine. Mar. Chem. 41, 343-351.

Saager, P.M., De Baar, H.J.W., Burkill, P.H., 1989. Manganese and iron in Indian Ocean waters. Geochim. Cosmochim. Acta 53, 2259-2267.

Sheu, D.D., Wong, G.T.F., Wang, C.H., Lin, S.C., 1999. Distribution of O-18: Exchanges between the East China Sea and adjoining waters. EOS, Trans., Amer. Geophys. Union 80 Suppl., 114.

Strickland, J.D.H., Parsons, T.R., 1972. A Practical Handbook of Seawater Analysis, Bull. 167. Fish. Res. Board Canada, Ottawa.

Tappin, A.D., Hydes, D.J., Burton, J.D., Statham, P.J., 1993. Concentrations, distributions and seasonal variability of dissolved $\mathrm{Cd}$, Co, $\mathrm{Cu}, \mathrm{Mn}, \mathrm{Ni}, \mathrm{Pb}$ and $\mathrm{Zn}$ in the English Channel. Cont. Shelf Res. 13, 941-969.

Toyota, Y., 1988. Behavior of Mn in the western North Pacific I. Manganese concentration off the Straits of Kii and in the Mariana Trough. J. Oceanogr. Soc. Japan 44, 157-162.

Walsh, J.J., Biscaye, P.E., Csanady, G.T., 1988. The 1983-1984 Shelf Edge Exchange Processes (SEEP)-I experiment: hypothesis and highlights. Cont. Shelf Res. 8, 435-456.

Wei, C.L., Sun, S.J., Huang, C.S., 1991. Manganese distribution in the water column off northeast Taiwan - A preliminary investigation. Acta Oceanogr. Taiwanica 26, 85-93.

Weiss, R.F., 1977. Hydrothermal manganese in the deep sea: scavenging residence time and $\mathrm{Mn} /{ }^{3} \mathrm{He}$ relationships. Earth. Planet. Sci. Lett. 37, 257-262.

Wheat, C.G., Feely, R.A., Mottl, M.J., 1996. Phosphate removal by oceanic hydrothermal processes: an update of the phosphorus budget in the oceans. Geochim. Cosmochim. Acta 60, 3593-3608.

Wong, G.T.F., Chao, S.Y., Li, Y.H., Shiah, F.K., 2000a. The Kuroshio edge exchange processes (KEEP) study - an introduction to hypotheses and highlights. Cont. Shelf Res. 20, 331-334.

Wong, G.T.F., Li, Y.-H., Chao, S.-Y., Chung, Y.-C., 2000b. KEEP exchange processes between the Kuroshio and the East China Sea Shelf. Cont. Shelf Res. 20, 335-347.

Wong, G.T.F., Pai, S.C., Liu, K.K., Liu, C.T., Chen, C.T.A., 1991. Variability of the chemical hydrography at the frontal region between the East China Sea and the Kuroshio north-east of Taiwan. Estuar. Coast. Shelf Sci. 33, 105-120.

Yeats, P.A., Strain, P.M., 1990. The oxidation of manganese in seawater: rate constants based on field data. Estuar. Coast. Shelf Sci. $31,11-24$.

Zhang, J., 1995. Geochemistry of trace metals from Chinese river/ estuary systems: an overview. Estuar. Coast. Shelf Sci. 41, 631-658. 